\section{PreValence of HIV InfECTION, SYPHILIS, AND SYPHILIS/HIV COINFECTION IN BLOOD DONORS FROM A BLOOD BANK OF PORTO Alegre, Southern Brazil}

\author{
Leonardo Santos da Silva1, Deborah Veiga Santos², \\ Cristine Blume Brietzke ${ }^{2}$, Laura Vicedo Jacociunas ${ }^{1}$
}

\begin{abstract}
Introduction: Hemotherapy consists of therapeutic treatments performed through blood transfusion. Clinical and serological screening of donors is an essential strategy to avoid transmission of infectious agents in blood transfusion. The objective of this study is to assess the seroprevalence of HIV infection, syphilis and syphilis/HIV coinfection in blood donors from a blood bank in Porto Alegre from 2014 to 2016.
\end{abstract}

Methods: Retrospective analysis of all blood donors registered on a software for managing hemotherapy services (Hemodot) of the Blood Bank in the Marques Pereira Laboratory, Porto Alegre / RS, from 2014 to 2016.

Results: Of the 28,173 users of the hemotherapy service during the study period, $198(0.70 \%)$ were positive for syphilis, HIV infection, or syphilis/HIV co infection. The prevalence of positive results for syphilis was $0.3 \%, 0.57 \%$ and $0.70 \%$ in 2014,2015 and 2016 , respectively, and for HIV infection was $0.18 \%, 0.14 \%$, and $0.16 \%$ for the same period. However, the prevalence of syphilis/HIV coinfection was not statistically significant.

Conclusions: The prevalence of syphilis increased significantly from 2014 to 2016. Hovever, this did not occur with HIV infection or with coinfection. This finding may reflect the requirement of the nucleic acid technique (NAT) for HIV screening in blood banks, a procedure that has been increasing transfusion safety and reducing the window period. Further studies may shed new light on the combined use of serological tests and NAT assays in blood banks to diagnose HIV cases and syphilis/HIV coinfection.

Keywords: Coinfection; transfusion safety; hemocenter; infectious disease; syphilis; HIV

Blood donation is a topic of global importance, especially with regard to blood transfusion safety ${ }^{1}$. Hemotherapy is a therapeutic treatment consisting of blood transfusion or transfusion of blood products and poses a high epidemiological risk, since blood, as a living tissue, is able to transmit several diseases ${ }^{2}$. Thus, quality parameters must be rigorously followed for blood procurement and for the selection and protection of recipients and donors ${ }^{3}$.

In Brazil, hemotherapy procedures are currently governed by a technical regulation of the Brazilian National Health Surveillance (Agência Nacional de Vigilância Sanitária, ANVISA): Ordinance no. 158, dated February 4, 2016, published in the Federal Official Gazette of February 5, 2016 (no. 2, Section 1, page 37$)^{4}$. This ordinance aimed to establish procedures to prevent the transmission of infection and improve the quality of the blood component to be transfused. The process of blood donation is conducted under a rigorous system divided into stages beginning with donor procurement and finishing with transfusion of donor's blood to the recipient The first stage, known as clinical screening, consists of taking the medical history of donor candidates to analyze their clinical history and their health behavior. The second stage is serological screening, which is the most common form of preventing the transmission of several etiologic agents ${ }^{5,6}$. In this context, after donation,
Clin Biomed Res. 2017;37(4):275-280

1 Biomedicine, Centro Universitário Metodista (IPA). Porto Alegre, RS, Brazil.

2 Hemotherapy Service, Laboratório Marques Pereira. Porto Alegre, RS, Brazil.

Corresponding author: Laura Vicedo Jacociunas laura.jacociunas@ipa.metodista.br Centro Universitário Metodista (IPA) Rua Cel. Joaquim Pedro Salgado, 80. 90240-060, Porto Alegre, RS, Brazil. 
blood undergoes laboratory screening, including immunohematologic tests, serological tests, and acid nucleic test (NAT) ${ }^{7,8}$ These regulations ensure blood donation safety. The article no. 130 of Ordinance no. 158/16 sets out mandatory highly sensitive laboratory serological tests to detect markers for the following conditions: syphilis, Chagas disease, hepatitis $B$, hepatitis $C$, human immunodeficiency virus (HIV), and human T-cell lymphotropic virus type I and/or II (HTLV I/II)4. Additionally, NAT started to be implemented according to the Brazilian legislation ${ }^{7}$. In some blood banks in the city of São Paulo, it was implemented to reduce HIV and hepatitis $C$ virus (HCV) transmission by blood transfusion and became mandatory for the entire Brazilian blood transfusion network, including public and private blood banks, in February 2014 under Ordinance no. 2712 dated November $12,2013^{8}$.

It is known that the disease most commonly transmitted by blood transfusion are hepatitis $\mathrm{C}$ and HIV. However, an important association has been observed between syphilis and HIV in recent years, especially with regard to their window periods. Therefore, screening tests in blood bank should be able to identify donors presenting with these diseases ${ }^{9}$.

Syphilis is a chronic infectious disease caused by the spirocheteTreponema pallidum ${ }^{10}$. For an effective diagnosis of syphilis, serological screening with non-treponemal and/or treponemal tests are recommended. Non-treponemal tests include venereal disease research laboratory (VDRL)) and rapid plasma reagin. Diagnosis is confirmed using treponemal tests, such as fluorescent treponemal antibody-Abs (FTA-Abs), Treponema Pallidum hemagglutination test, TPHA, and enzyme-linked immunosorbent assay, ELISA ) 11,12. Treatment for this condition is well-established, with penicillin as the drug of choice. Recently, bacterial resistance to this drug has made syphilis a public health problem and the production of penicillin has become scarce. Intramuscular benzathine penicillin is the drug of choice in most cases, except for congenital syphilis and neurosyphilis, when crystalline penicillin $G$ sodium is indicated ${ }^{13,14}$. However, even when treatment is effective, results for treponemal tests remain positive, a phenomenon known as serological scar ${ }^{15,16}$. From 2010 to June 2016, the Notifiable Diseases Information System (Sistema de Informação de Agravos de Notificação, SINAN) notified a total of 227,663 cases of syphilis acquired in Brazil, $62.1 \%$ coming from the southeastern region of the country, $20.5 \%$ from the southern region, $9.3 \%$ from the northeastern region, $4.7 \%$ from the midwestern region, and $3.4 \%$ from the northern region. Overall, 136,835 cases were male and 90,755 were female. Moreover, patients aged from 20 to 29 years accounted for $31.2 \%$ of the cases. In $2015,65,878$ cases of syphilis were notified, of which $39,638(60.2 \%)$ were male and $26,220(39.8 \%)$ were female ${ }^{17}$.

$\mathrm{HIV}$, the causative agent of acquired immunodeficiency syndrome (AIDS), is a retrovirus classified into the subfamily Lentiviridae and containing RNA genetic material ${ }^{18}$. Brazil is one of the countries that provides free universal antiretroviral (ARV) therapy ${ }^{19}$. The use of this drug to treat HIV infection has reduced morbidity and mortality rates, thus increasingly making AIDS a chronic controllable disease worldwide ${ }^{20}$.

HIV infection is diagnosed using serological tests through ELISA, enzyme linked fluorescent assays, immunofluorescence assays, particle agglutination assays chemiluminescence assays, and microparticle enzyme immunoassays ${ }^{9}$. Blood banks are required by the Brazilian Ministry of Health to perform tests that detect antibodies against HIV, regardless of the method or allow for the combined detection of antibody against HIV + HIV p24 antigens and tests that aim to detect HIV nucleic acid. To ensure transfusion, one positive test is already considered and indication for discarding blood bags ${ }^{4}$. The implementation of the NAT in the testing routine for the laboratory detection of the virus reduced the estimated window period compared with serological tests for HIV detection from 22 to 10 days ${ }^{21}$.

From 2007 to June 2016, SINAN notified 136,945 cases of HIV infection in Brazil, 71,396 (52.1\%) coming from the southeastern region, $28,879(21.1 \%)$ from the southern region, 18,840 (13.8\%) from northeastern region, $9,152(6.7 \%)$ from the midwestern region, and $6,868(6.3 \%)$ from the northern region. Overall, 92,149 of patients were male and 44,766 were female, and $52.3 \%$ were aged fro 20 to 34 years old. In 2015, 32,321 cases of HIV infection were notified, $22,672(70.2 \%)$ in male and 9,637 (29.8\%) in female ${ }^{22}$.

Both syphilis and HIV are transmitted mainly by unprotected sex. However, the presence of syphilis increases the risk of contracting HIV from ulcerated genital lesions, mucosal disruption, inflammation, and genital secretions. Therefore, all patients with syphilis should undergo HIV testing, and all positive HIV patients should be tested for syphilis on a regular basis $^{23-25}$.

Several studies reported that syphilis, such as other acute infections, leads to increased viral load and reduced CD4 cell count. This transient increase in viral load results in increased risk for HIV transmission among patients with the two diseases and is a consequence of activation of immunological response ${ }^{26-28}$. Studies suggest that the window period for syphilis may predispose to HIV infection, i.e., HIV transmission is facilitated in patients with syphilis because both conditions share 
the same route of transmission. Additionally, the base of primary chancre of syphilis have a high number of $T$ cells and macrophages, which are the primary targets of $\mathrm{HIV}^{9,25,29}$.

The window period of syphilis is short, since tests may yield positive results some days after the onset of primary stage lesions ${ }^{30}$. Some tests, such as VDRL, RPR, TPHA, and FTA-abs, become positive within from 3 weeks to 3 months; Conversely, tests for antibody against HIV become positive within 6 weeks from 3 months, whereas Western blot and p24 antigen tests, within 2 weeks ${ }^{31}$. Within this context, the present study sought to evaluate the prevalence of HIV infection, syphilis, and syphilis/HIV coinfection in blood donors from a blood bank in Porto Alegre, southern Brazil, from 2014 to 2016.

\section{METHODS}

A quantitative, descriptive, retrospective study was carried out to analyze information from all blood donors registered at the database of the blood bank of Laboratório Marques Pereira at Porto Alegre, southern Brazil, for the period from January 1st, 2014 to December 31, 2016. This study was approved by the Research Ethics Committee of Centro Universitário Metodista IPA and registered at Platarforma Brasil (protocol number 1.709.050).

The sample of the present study included data from 28,173 hemotherapy service users at the Laboratório Marques Pereira. Data records were assessed using a software for managing hemotherapy services (Hemodot) to collect information on HIV I/II serology, NAT assays, VDRL serology for syphilis to analyze the frequency of these contagious diseases whether alone or in combination among the study population.
To that end, data were inserted into the Statistical Package for Social Sciences (SPSS) software and analyzed considering a level of significance of $p<0,05$.

Results were expressed as numbers and percentages. In the blood bank under studies, donor blood were assessed by chemiluminescent microparticle immunoassays with specificity of $99.5 \%$ and sensitivity of $100 \%$, as recommended by the Brazilian Ministry of Health. According to manufacturer's instructions, samples with serological values $\geq 1$ are reactive and $<1$ are not. However, our service establishes a margin of safety of $15 \%$ (grey zone), recommending that results within this zone should be considered indeterminate and donors should be asked to return to the service to have blood drawn again.

\section{RESULTS}

The total number of donor candidates from 2014 to 2016 was 28,173 donors, distributed as follows: 8,695 in $2014,10,009$ in 2015, and 9,469 in 2016. Over the 3 -year period, the number of blood bags positive for syphilis, HIV infection, and syphilis/HIV coinfection was $198(0.70 \%)$. Data for positive serological and NAT assays are presented in Table 1.

The prevalence of syphilis-positive blood bags gradually increased over the years, while the prevalence of HIV-positive cases did not change significantly. All reactive serological HIV tests were confirmed by NAT assays, which were also positive for HIV infection. The prevalence of syphilis in blood donor is greater compared with that of HIV cases. Conversely, the prevalence of syphilis/HIV coinfection was not statistically significant, as shown in Figure 1.

Table 1: Total of positive cases of syphilis, HIV, and syphilis/HIV coinfection per year.

\begin{tabular}{|c|c|c|c|c|c|c|}
\hline & Total & $(\%)$ & Men & $(\%)$ & Women & $(\%)$ \\
\hline \multicolumn{7}{|c|}{2014} \\
\hline Positive results for syphilis & 26 & $(0.3)$ & 15 & $(0.17)$ & 11 & $(0.13)$ \\
\hline Positive results for HIV infection & 16 & $(0.18)$ & 13 & $(0.15)$ & 3 & $(0.03)$ \\
\hline Positive results for syphilis/HIV coinfection & 0 & $(0.0)$ & 0 & $(0.0)$ & 0 & $(0.0)$ \\
\hline Total of donors/year & 8695 & $(100)$ & & & & \\
\hline \multicolumn{7}{|c|}{2015} \\
\hline Positive results for syphilis & 57 & $(0.57)$ & 33 & $(0.33)$ & 24 & $(0.24)$ \\
\hline Positive results for HIV infection & 14 & $(0.14)$ & 9 & $(0.09)$ & 5 & $(0.05)$ \\
\hline Positive results for syphilis/HIV coinfection & 3 & $(0.03)$ & 3 & $(0.03)$ & 0 & $(0.0)$ \\
\hline Total of donors/year & 10009 & $(100)$ & & & & \\
\hline \multicolumn{7}{|c|}{2016} \\
\hline Positive results for syphilis & 66 & $(0.70)$ & 34 & $(0.36)$ & 32 & $(0.34)$ \\
\hline Positive results for HIV infection & 15 & $(0.16)$ & 4 & $(0.04)$ & 11 & $(0.12)$ \\
\hline Positive results for syphilis/HIV coinfection & 1 & $(0.01)$ & 1 & $(0.01)$ & 0 & $(0.0)$ \\
\hline Total of donors/year & 9469 & $(100)$ & & & & \\
\hline
\end{tabular}

Source: designed by the author. 


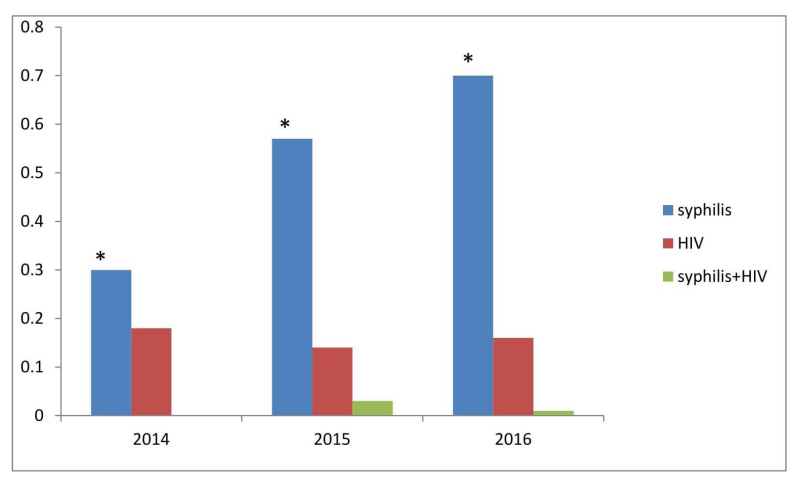

Figure 1: Prevalence of positive serology for syphilis, HIV infection, and syphilis/HIV infection in the blood bank of Laboratório Marques Pereira from 2014 to 2016; *results with a significance level of $p<0.05$. Source: designed by the author.

\section{DISCUSSION}

Currently, there is a clear concern from hemotherapy services in ensuring blood transfusion safety both for donors and recipients, which has been increasing reducing the frequency of transmission of infectious diseases by blood transfusion. This reduction may be achieved through effective screening for these diseases in blood banks, including donor procurement, epidemiological and clinical analysis of donor health status, and laboratory screening, in order to prevent the risk of contamination and thus increase safety

Our findings revealed the prevalence of positive serology for syphilis increased on an yearly basis from 2014 to 2016 . This fact may be explained by the high prevalence of syphilis in the general population, by the shortage of penicillin (the antibiotic of first choice for the treatment of syphilis), and by the fact that most infections are diagnosed after solidarity initiatives such as blood donation, and promotes the spread of both infections. This finding corroborates surveillance data showing that the prevalence of syphilis increased $42.7 \%$ in $2015^{17}$. Conversely, positive HIV serology remained stable over the 3-year period. These findings may be justified by the mandatory implementation of NAT assays for HIV infection in blood banks, which reduced the window period, because of the sensitivity of the test, since it is required to have a sensitivity of $100 \%$, with no acceptable false negatives ${ }^{4}$.

In a study conducted between December 2011 and May 2012 at the blood bank of the Edéa Regional Hospital, Cameroon, the seroprevalence of HIV was $4.1 \%$, indicating a reduction in HIV cases in the country over the last decade due to the implementation of prevention programs ${ }^{32,33}$.

In the present study, the prevalence of HIV infection, syphilis, and HIV/syphilis coinfection from 2014 to 2016 was higher in males. A study conducted by Rohr et al. to assess the profile of unfit donor candidates at the hospital of Santo Ângelo, southern Brazil found that the main cause for ineligibility in men was high risk behavior and multiple sex partners. This may result from greater sexual freedom, homosexual behavior, extramarital affairs, and reduced use of condoms, all of which make men more susceptible to contract a sexually transmitted disease. Conversely, the main cause for ineligibility in women was low hemoglobin or hematocrit. This behavioral information obtained from the study by Rohr et al. may explain the results from the present study showing a higher prevalence of syphilis in men.

With a prevalence of $0.014 \%$, HIV/syphilis coinfection was not very prevalent in the study population from 2014 to 2016, although the two diseases share the same route of transmission. In contrast, a previous study conducted at Hemocentro de Guarapuava, southern Brazil found a much higher prevalence of HIV/syphilis coinfection. From January 2009 to December 2013, there were 28,851 blood donations, of which $1,651(5.6 \%)$ were positive for infectious diseases. Of the 1,651 positive donations, $76(4.7 \%)$ were coinfected with syphilis/HIV ${ }^{34}$. In the present study, which covered from 2014 to 2016 , the non-statitiscally significant prevalence of syphilis/HIV coinfection $(0.014 \%)$ may be explained by the period of data collection and by the peculiarites of the blood bank under study, which also represents a limitation of this study. It is important to note that a positive HIV serology does not mandatorily mean positive syphilis serology. One condition is known to predispose to the other, but there is no dependence relationship between them. The analysis of coinfection with these diseases has an important role in assessing the window period and may provide data for future epidemiological studies to help treatment of positive cases, since both conditions share the same route of infection.

A study conducted in Campinas, southeastern Brazil, assessed the prevalence of syphilis/HIV coinfection in patients registered on an electronic system for the notification of sexually transmitted diseases (STD) (SINDST) at a STD/HIV referral center from January 2004 to December 2012. Overall, 3,106 cases of STD were notified. Of these, 860 presented with at least one episode of syphilis. Of the patients with syphilis, $781(90.8 \%)$ were male and $79(9.2 \%)$ were female. In turn, there were $377(43.8 \%)$ cases of syphilis/HIV coinfecction, of which 354 were male and 23 were female ${ }^{35}$. Another study conducted from 1997 to December 2014 in Rio de Janeiro, southern Brazil, with HIV seropositive patients assessed the prevalence of syphilis/HIV during HIV treatment. Of 793 HIV-positive patients, 417 met study requirements, of which $270(64.7 \%)$ 
were male, $141(33.8 \%)$ were female, and $6(1.4 \%)$ were transvestite/transexual. When only coinfected patients were analyzed, 81 met study requirements, of which $67(82.7 \%)$ were male, $10(12.3 \%)$ were female, and 4 (4.4\%) were transvestite/transexual ${ }^{36}$. The prevalence of syphilis/HIV coinfection was $19.4 \%$; however, it is worth noting that the period covered in the study was long and that there may have been a change in the epidemiological profile of the study over this period.

Across-sectional study determined the prevalence of syphilis and factors associated with syphilis infection in patients with HIVIAIDS treated at Hospital Santa Casa de Misericórdia de Vitória, southeastern Brazil, from August 2010 to September 2011. Of 498 patients selected, 438 (88\%) HIV-positive patients HIV were included in the study, of which $241(55 \%)$ were male and 197 (45\%) were female. Of the 438 HIV-positive patients, $23(5.3 \%)$ were coinfected with syphilis, 20 $(87 \%)$ men and $3(13 \%)$ women ${ }^{37}$. Another study conducted in Porto Alegre, southern Brazil, assessed the prevalence of coinfection with syphilis in HIV seropositive patients from 1991 to November 2008. Of 2,262 patients infected with HIV, only 1,012 met criteria for inclusion in the study. Of these, 580 (57\%) were male and $432(43 \%)$ were female. The prevalence of syphilis/HIV coinfection in this study was $20,5 \%$ (208 cases, 166 men and 42 women) ${ }^{38}$. It is worth emphasizing that there was a great variation in the results found in the literature, resulting from differences in study design, diagnostic tests, and study period.

Technological and scientific advances are remarkably improving attempts to minimize the risks posed by blood transfusion. Fourth-generation ELISA assays have a sensitivity of nearly $100 \%$. Recently, the mandatory implementation of nucleic acid amplification test for the screening of HIV and HCV in blood banks has reduced the window period. It should be noted that this study aimed to assess coinfection in blood donors from a blood bank in Porto Alegre, southern Brazil. However, there is scarce clinical evidence on the topic in the literature. Thus, further studies covering different study periods are needed to investigate satisfactory results and to explain the findings obtained in the present study. Therefore, this study sheds new light on the combined use of serological tests and NAT assays in blood banks to diagnose HIV cases and syphilis/HIV coinfection.

\section{Conflicts of interest}

The authors declare no conflicts of interest.

\section{REFERENCES}

1. Rodrigues RSM, Reibnitz KS. Estratégias de captação de doadores de sangue: uma revisão integrativa da literatura. Texto Contexto - Enferm. 2011;20(2):384-91.

2. Liberato SMD, Costa IKF, Pessoa CM, Nogueira MAC, Araújo MDMN, Torres GV. Perfil dos doadores de sangue do Hemocentro Público de Natal/ RN. Rev Pesqui Cuid Fundam Online. 2013;5(1):3523-30.

3. Monteiro DK, Comparsi B. Principais fatores associados a inaptidão temporária e permanente de candidatos á doação de sangue. Rev Saúde Integrada. 2015;8:15-6.

4. Brasil. Ministério da Saúde. Portaria $n^{\circ}$. 158, de 04 de fevereiro de 2016. Redefine o regulamento técnico de procedimentos hemoterápicos. Diário Oficial da República Federativa do Brasil. 2016 Fev 05; n² 25, Seção 1, p. 37 p. [citado 2017 Mai 28]. Disponível em: http://www. hemocentro.unicamp.br/dbarquivos/ portaria_ms_n_158_de_04_de_ fevereiro 2016.pdf.
5. Rohr JI, Boff D, Lunkes DS. Perfil dos candidatos inaptos para doação de sangue no serviço de Hemoterapia do Hospital Santo Ângelo, RS, Brasil. Rev Pat Trop. 2012;41(1):27-35.

6. Seitz R, Heiden M. Quality and Safety in Blood Supply in 2010. Transfus Med Hemother. 2010;37(3):1127. PMid:20577599. http://dx.doi. org/10.1159/000314497.

7. BRASIL. Ministério da Saúde. Portaria $n^{\circ} 262$, de 05 de fevereiro de 2002. Diário Oficial da União. 2002 Fev 02; Seção 1. [citado 2017 Mai 20]. Disponível em: http://bvsms.saude. gov.br/bvs/saudelegis/gm/2002/ prt0262_05_02_2002.html.

8. Brasil. Ministério de Saúde. Portaria $n^{\circ} 2.712$ de 12 de novembro de 2013. Redefine o Regulamento Técnico de Procedimentos Hemoterápicos. Diário Oficial da União. 2013 Nov 13; n²21, Seção 1. [citado em 2017 mai 20]. Disponível em: http:// www.uel.br/hu/hemocentro/pages/
arquivos/PORTARIA\%20N\%20 $2.712 \% 20 D E \% 2012 \% 20 D E \% 20$ NOVEMBRO\%20DE\%202013.pdf.

9. Vaz AJ, Takei K, Bueno EC. Imunoensaios: fundamentos e aplicações. 1. ed. Rio de Janeiro: Guanabara Koogan; 2007.

10. Lopes L, Ferro-Rodrigues R, Llobet S, Lito L, Borges-Costa J. Sífilis: prevalência num hospital de Lisboa. Acta Med Port. 2016;29(1):525. PMid:26926899. http://dx.doi. org/10.20344/amp.6247.

11. Lautenschlager S. Cutaneous manifestations of syphilis: recognition and management. Am J Clin Dermatol. 2006;7(5):291-304. PMid:17007540. http://dx.doi.org/10.2165/00128071200607050-00003.

12. Tipple C, Taylor GP. Syphilis testing, typing, and treatment follow-up: a new era for an old disease. Curr Opin Infect Dis. 2015;28(1):5360. PMid:25485649. http://dx.doi. org/10.1097/QCO.0000000000000124. 
13. Kent ME, Romanelli F. Reexamining syphilis: an update on epidemiology, clinical manifestations, and management. Ann Pharmacother. 2008;42(2):226-36. PMid:18212261. http://dx.doi.org/10.1345/aph.1K086.

14. Clement ME, Okeke NL, Hicks CB. Treatment of syphilis: a systematic review. JAMA. 2014;312(18):190517. PMid:25387188. http://dx.doi. org/10.1001/jama.2014.13259.

15. Lago EG. Current perspectives on prevention of mother-to-child transmission of syphilis. Cureus. 2016;8(3):e525. PMid:27081586.

16. Swartzendruber A, Steiner RJ, Adler MR, Kamb ML, Newman LM. Introduction of rapid syphilis testing in antenatal care: A systematic review of the impact on HIV and syphilis testing uptake and coverage. Int J Gynaecol Obstet. 2015;130(Suppl 1):S1521. PMid:26001704. http://dx.doi. org/10.1016/j.jjgo.2015.04.008.

17. Brasil. Ministério da Saúde. Secretaria de Vigilância em Saúde. Boletim Epidemiológico Sífilis 2016. Brasília: Ministério da Saúde; 2016.

18. Chinen J, Shearer WT. Molecular virology and immunology of HIV infection. J Allergy Clin Immunol. 2002;110(2):189-98. PMid:12170257. http://dx.doi.org/10.1067/ mai.2002.126226.

19. Polejack L, Seidl EMF. Monitoramento e avaliação da adesão ao tratamento antirretroviral para HIV/aids: desafios e possibilidades. Cien Saude Colet. 2011;5(Supl. 1):1201-8.

20. Brogly $S$, Williams $P$, Seage GR 3RD, Oleske JM, Van Dyke R, McIntosh K, and the PACTG 219C Team. Antiretroviral treatment in pediatric HIV infection in the United States: from clinical trials to clinical practice. JAMA. 2005;293(18):221320. PMid:15886376. http://dx.doi. org/10.1001/jama.293.18.2213.

21. Petry A. Implantação dos testes de amplificação de ácidos nucléicos HIV/ HCV Bio Manguinhos ${ }^{\circledR}$ na triagem de doadores de sangue: questões epidemiológicas e logísticas [tese]. Florianópolis: Programa de PósGraduação em Saúde Coletiva, Universidade Federal de Santa Catarina; 2013
22. Brasil. Ministério da Saúde. Secretaria de Vigilância em Saúde. Departamento de DST, Aids e Hepatites Virais. Boletim Epidemiológico: HIVIAIDS 2016. Brasília: Ministério da Saúde; 2016.

23. Zetola NM, Klausner JD. Syphilis and HIV infection: an update. Clin Infect Dis. 2007;44(9):12228. PMid:17407043. http://dx.doi. org/10.1086/513427.

24. Avelleira JCR, Bottino G. Sífilis: diagnóstico, tratamento e controle. An Bras Dermatol. 2006;82(2):11126. http://dx.doi.org/10.1590/S036505962006000200002

25. Solomon MM, Mayer KH, Glidden DV, Liu AY, McMahan VM, Guanira JV, et al, and the PrEx Study Team. Syphilis predicts HIV incidence among men and transgender women who have sex with men in a preexposure prophylaxis trial. Clin Infect Dis. 2014;59(7):10206. PMid:24928295. http://dx.doi. org/10.1093/cid/ciu450.

26. Kofoed K, Gerstoft J, Mathiesen LR, Benfield T. Syphilis and human immunodeficiency virus (HIV)1 coinfection: influence on CD4 T-cell count, HIV-1 viral load, and treatment response. Sex Transm Dis. 2006;33(3):143-8. PMid:16505739. http://dx.doi.org/10.1097/01. olq.0000187262.56820.c0.

27. Repiso B, Frieyro M, Rivas-Ruiz F, Troya M. Uso de preservativo y número de parejas sexuales en hombres que tienen sexo con hombres con sífilis. Actas Dermosifiliogr. 2010;101(10):847-52. PMid:21159260. http://dx.doi.org/10.1016/j. ad.2010.06.014

28. Zetola NM, Engelman J, Jensen TP, Klausner JD. Syphilis in the United States: an update for clinicians with an emphasis on HIV coinfection. Mayo Clin Proc. 2007;82(9):1091102. PMid:17803877. http://dx.doi. org/10.4065/82.9.1091.

29. Burchell AN, Allen VG, Moravan V, Gardner S, Raboud J, Tan DH, et al. Patterns of syphilis testing in a large cohort of HIV patients in Ontario, Canada, 2000-2009. BMC Infect Dis. 2013;13:246. PMid:23710699.
30. Araújo MAL, Freitas SC, Moura HJ, Gondim AP, Silva RM. Prevalence and factors associated with syphilis in parturient women in Northeast, Brazil. BMC Public Health. 2013;16:206. PMid:23497370.

31. Ooi C. Testing for sexually transmitted infections. Aust Prescr. 2007;30(1):813. http://dx.doi.org/10.18773/ austprescr.2007.005.

32. Noubiap JJN, Joko WYA, Nansseu JRN, Tene UG, Siaka C. Sero-epidemiology of human immunodeficiency virus, hepatitis B and $C$ viruses, and syphilis infections among first-time blood donors in Edea, Cameroon. Int J Infect Dis. 2013;17(10):e832-7. PMid:23317526. http://dx.doi.org/10.1016/j. ijid.2012.12.007.

33. Tagny CT, Owusu-Ofori S, Mbanya $D$, Deneys V. The blood donor in sub-Saharan Africa: a review. Transfus Med. 2010;20(1):1-10. PMid:19725906. http://dx.doi.org/10.1111/j.13653148.2009.00958.x.

34. Farinazzo MN. Perfil de doadores de sangue com sorologia positiva a doenças infectocontagiosas no hemocentro de Guarapuava - PR. Curitiba: Hemoterapia; 2015. p. $287-$ 96.

35. Almeida VC. A Sifilis em população vulnerável: Epidemiologia e fatores associados à reinfecção e coinfecção com HIV em Campinas, São Paulo [dissertação]. São Paulo: Faculdade de Ciências Médicas; 2014.

36. Souza AP. Coinfecção HIV e sífilis: prevalência e fatores de risco [dissertação]. Rio de Janeiro: Escola Nacional de Saúde Pública Sergio Arouca; 2015.

37. Callegari FM. Prevalência de sífilis em pacientes com HIVIAIDS atendidos em serviço de atendimento especializado em Vitória, ES [dissertação]. Vitória: Universidade Federal do Espírito Santo; 2011.

38. Adolf R, Bercht F, Aronis ML, Lunardi LW, Schechter M, Sprinz E. Prevalence and risk factors associated with syphilis in a cohort of HIV positive individuals in Brazil. AIDS Care. 2012;24(2):252-8. PMid:21780954. 